\title{
Notes on oil sources for the bee genus Caenonomada (Hymenoptera, Apidae, Tapinotaspidini)
}

\author{
Antonio J. C. Aguiar ${ }^{1} \&$ Gabriel A. R. Melo
}

${ }^{1}$ Museu de Zoologia da Universidade de São Paulo, Av. Nazaré 481, 04263-000 São Paulo-SP, Brazil. ajcaguiar@gmail.com

${ }^{2}$ Univ. Fed. Parana, Dept. Zool., Lab. Biol. Comparada Hymenoptera, Caixa Postal 19020, 81531980 Curitiba-PR, Brazil. garmelo@ufpr.br

\begin{abstract}
Notes on oil sources for the bee genus Caenonomada (Hymenoptera, Apidae, Tapinotaspidini). It is reported for the first time oil collecting by bees of the genus Caenonomada on flowers of Plantaginaceae. Females of Caenonomada unicalcarata were observed collecting oil on flowers of Angelonia cornigera, and males and females of Caenonomada bruneri and C. aff. unicalcarata were observed on flowers of Angelonia and Monopera (Plantaginaceae). The record of Caenonomada on Plantaginaceae suggests the use of trichomatic oil glands as a primitive condition in the tribe Tapinotaspidini.
\end{abstract}

KEYWORDS. Oil-bees; oil-flowers; glandular trichomes; Neotropical.

RESUMO. Notas sobre fontes de óleos florais do gênero Caenonomada (Hymenoptera, Apidae, Tapinotaspidini). Pela primeira vez é reportado a coleta de óleo por Caenonomada em Plantaginaceae. Fêmeas de Caenonomada unicalcarata foram observadas coletando óleo em flores de Angelonia cornigera, e fêmeas e machos de Caenonomada bruneri e Caenonomada aff. unicalcarata em flores de Angelonia e Monopera (Plantaginaceae). O registro de Caenonomada em Plantaginaceae sugere uma condição mais primitiva para o uso de glândulas tricomáticas de óleo na tribo Tapinotaspidini.

PALAVRAS-CHAVE. Abelhas coletoras de óleos; flores produtoras de óleos; glândulas tricomáticas; Neotropical.

Among oil-collecting bee groups, the tribe Tapinotaspidini is the most diversified in terms of morphological structures and adaptations to collect oil. Their oil collecting apparatuses are mainly composed of patches of specialized setae on fore and/or mid legs, except for Tapinotaspoides which possesses specialized setae on the sterna (Roig-Alsina 1997; Cocucci et al. 2000). Regarding their host plant families, the genus Monoeca is associated to Malpighiaceae (Rozen et al. 2006; Sigrist \& Sazima 2004), Chalepogenus to Solanaceae, Calceolariaceae, Iridaceae (Vogel 1974; Cocucci \& Vogel 2001; Cocucci et al. 2000), and Malpighiaceae (Aguiar, unpublished), Tapinotaspis to Plantaginaceae, Iridaceae and Solanaceae (Cocucci 1991, Cocucci \& Vogel 2001, Cocucci et al. 2000), Lanthanomelissa to Iridaceae (Cocucci \& Vogel 2001, Truylio et al. 2002; Rozen et al. 2006), Arhysoceble to Plantaginaceae (Vogel \& Machado 1991), Malpighiaceae (Faria-Mucci et al. 2003) and Krameriaceae (Aguiar, unpublished), Trigonopedia to Malpighiaceae (Aguiar, unpublished) and the genera of the Paratetrapedia lineage (Xanthopedia, Lophopedia, Tropidopedia and Paratetrapedia s. str.) are mainly associated to Malpighiaceae (Sazima \& Sazima 1989; Sigrist \& Sazima 2004; Pedro 1994), with some records on Orchidaceae (Mickeliunas et al. 2006) and Krameriaceae (Simpson 1989). Differently from the remaining genera, the oil collecting apparatus of Tapinotaspoides are associated to non-floral glandular trichomes of diverse plant families (Melo \& Gaglianone 2005).

Based on the setal morphology of the fore legs, RoigAlsina (1997) suggested that species of Caenonomada could be associated to plant families with trichromatic oil glands. The oil collecting apparatus of Caenonomada is located on fore tarsomeres 1-4 and is composed of stiff flattened setae on the outer surface and finely branched setae on the inner surface of the tarsomeres. This morphology is somewhat similar to that present in species of Chalepogenus and Centris hyptidis (Roig-Alsina 1997; Cocucci et al. 2000). The only record of oil source for Caenonomada was reported by Cocucci et al. (2000), who collected one female of Caenonomada bruneri on flowers of Cypella gracilis (Iridaceae) and also observed pollen grains of this plant on the bee's scopae.

We report here anecdotal observations of males and females of Caenonomada on oil-flowers of three species of plants, currently placed in Plantaginaceae. The bee vouchers collected on Mato Grosso do Sul were deposited at Coleção Entomológica Padre Jesus Santiago Moure, Departamento de Zoologia, Universidade Federal do Paraná, and the bee vouchers collected on Piauí were deposited on Museu de Zoologia da Universidade de São Paulo. Plant material was deposited at Herbário do Departamento de Botânica (UPCB), Universidade Federal do Paraná. 

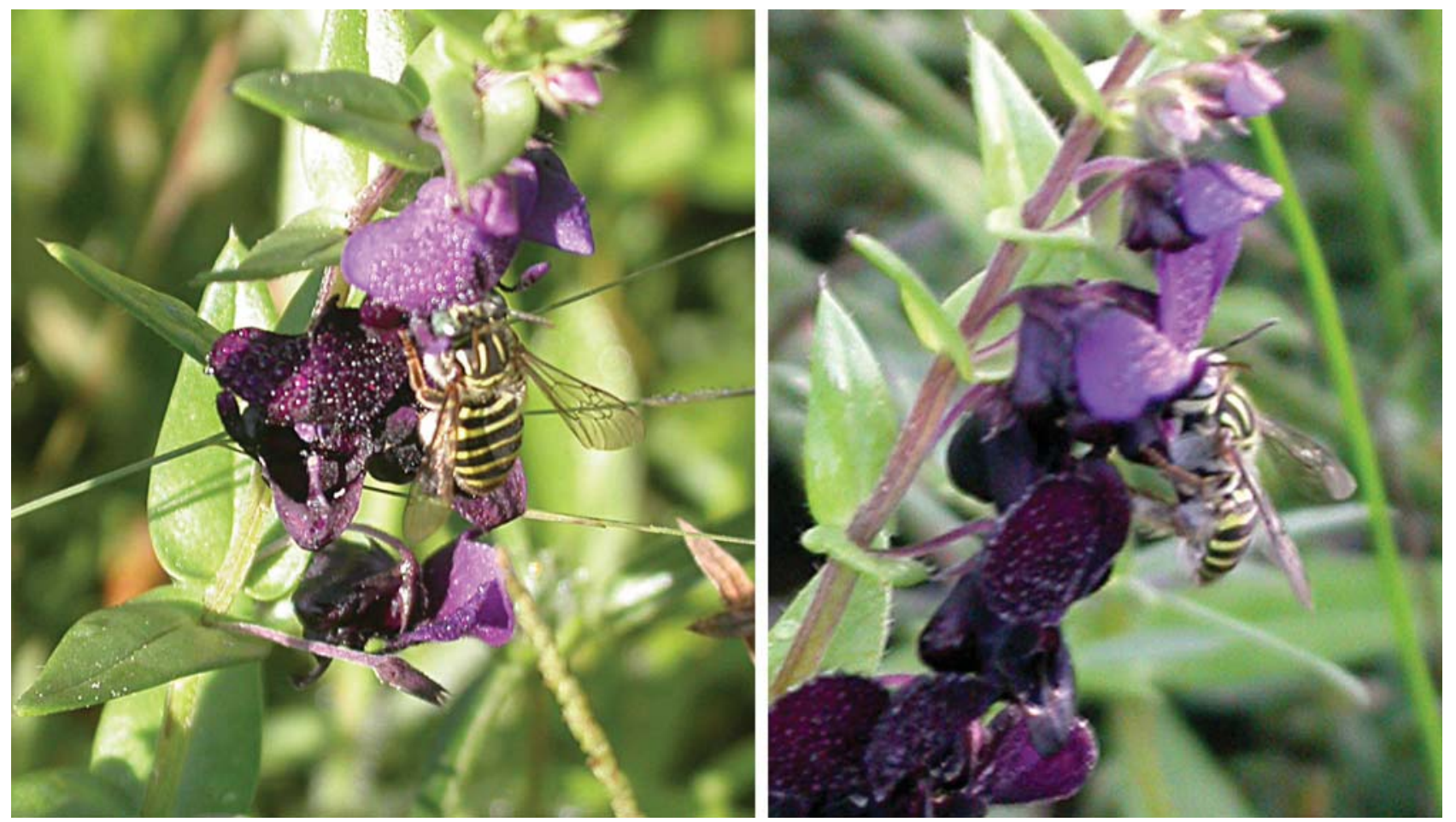

Fig. 1. Females of Caenonomada unicalcarata visiting flowers of Angelonia cornigera in an area of Caatinga vegetation at São Miguel do Tapuio, Piauí, northeastern Brazil. The photography at right, although not in focus, shows how the bee positions itself during foraging, touching the plant reproductive structures with its head.

The first set of observations was carried out on February 24, 2004, between 11:30 and 13:00, in an abandoned pasture field composed by herbaceous plants and some scattered trees, in an area of Chaco vegetation, near Porto Murtinho (Mato Grosso do Sul, Brazil). Females of Caenonomada bruneri Ashmead, 1899 were seen on flowers of Angelonia salicariifolia Bonpl, and males of Caenonomada aff. unicalcarata (Ducke, 1908) and one female C. bruneri on flowers of Monopera perennis (Chodat \& Hassl.) Barringer. The few observed visits were fast and no detailed notes of the female behavior were taken. A few females of Centris (Hemisiella) tarsata Smith, 1874 were also observed and collected on flowers of A. salicariifolia.

Specimens of both species of Caenonomada collected while visiting other plant species at the site were examined to check for the presence of pollen of Plantaginaceae in their bodies. Pollen grains from anthers of the dry plant vouchers were mounted in glycerin-jelly slides and compared to that deposited on the bees' head. Both plant species have a very similar pollen morphology (small, tricolporate grains), as already observed by Santos (1997). Ten out of 14 females and seven out of nine males of $C$. aff. unicalcarata had identical pollen grains on the upper clypeus and supraclypeal area. In the case of $C$. bruneri, 16 out of 33 females had pollen of Plantaginaceae on their face.

More recently (April 2008), numerous females of Caenonomada unicalcarata were observed visiting and collecting oil on flowers of Angelonia cornigera (Fig. 1) in an area of Caatinga at São Miguel do Tapuio, Piauí, in northeastern Brazil. A large number of males of $C$. unicalcarata were also observed flying around the flowers, probably in search for females. Machado et al. (2002) studied the pollination of Angelonia cornigera, but did not report the presence of Caenonomada on the flowers.

The records of Caenonomada collecting oil on Angelonia are in accordance with the suggestion of Roig-Alsina (1997) that the oil-collecting apparatus of this genus is morphologically adapted to trichromatic glands. Although the basal lineages in the phylogeny of Tapinotaspidini are not well resolved, the association of Caenonomada with Plantaginaceae suggests the use of trichomatic oil glands as a primitive condition in the tribe.

Acknowledgments. We thank Vinicius Castro Souza and Aline Cristina Martins for helping in the identification of the Plantaginaceae. To FAPESP (Proc. 2008/00499-7) for financial support.

\section{REFERENCES}

Cocucci, A. 1991. Pollination biology of Nierembergia (Solanaceae). Plant Systematics and Evolution 174: 17-35.

Cocucci, A.; A. Sersic \& A. Roig-Alsina. 2000. Oil-collecting structures in Tapinotaspidini: their diversity, function and probable origin (Hymenoptera: Apidae). Mitteilungen der Münchner Entomologischen Gesellschaft 90: 51-74.

Cocucci, A. \& S. Vogel. 2001. Oil-producing flowers of Sisyrinchium species (Iridaceae) and their pollinators in southern South America. Flora 196: 26-46. 
Faria-Mucci, G.; M. A. Melo \& L. A. O. Campos. 2003. A fauna de abelhas (Hymenoptera, Apoidea) e plantas utilizadas como fonte de recursos florais, em um ecossistema de campos rupestres em Lavras Novas, Minas Gerais, Brasil, p. 241-256. In: G. A. R. Melo \& I. Alves-dos-Santos (eds). Apoidea Neotropica: homenagem aos 90 anos de Jesus de Santiago Moure. Editora Unesc, Criciúma, xvi+320 p.

Machado, I. C.; S. Vogel \& A. V. Lopes. 2002. Pollination of Angelonia cornigera Hook. (Scrophulariaceae) by long-legged, oil-collecting bees in NE Brazil. Plant Biology 4: 352-359.

Melo, G. A. R. \& M. C. Gaglianone. 2005. Females of Tapinotaspoides, a genus in the oil-collecting bee tribe Tapinotaspidini, collect secretions from non-floral trichomes (Hymenoptera, Apidae). Revista Brasileira de Entomologia 49: 167-168.

Mickeliunas, L.; E. Pansarin \& M. Sazima. 2006. Biologia floral, melitofilia e influência de besouros Curculionidae no sucesso reprodutivo de Grobya amherstiae Lindl. (Orchidaceae: Cyrtopodiinae). Revista Brasileira de Botânica 29: 251-258.

Pedro, S. R. M. 1994. Interações entre abelhas e flores em uma área de cerrado no NE do estado de São Paulo: abelhas coletoras de óleo (Hymenoptera: Apoidea: Apidae), p. 243-255. In: Anais do I Encontro sobre Abelhas. Ribeirão Preto, Universidade de São Paulo, Faculdade de Filosofia, Ciências e Letras de Ribeirão Preto.

Roig-Alsina, A. 1997. A generic study of the bees of the tribe Tapinotaspidini, with notes on the evolution of their oil-collecting structures (Hymenoptera, Apidae). Mitteilungen der Münchner Entomologischen Gesellschaft 87: 3-21.
Rozen, J. G.; G. A. R. Melo; A. J. C. Aguiar \& I. Alves-dos-Santos. 2006 Nesting biologies and immature stages of the tapinotaspidine bee genera Monoeca and Lanthanomelissa and of their osirine cleptoparasites Protosiris and Parepeolus (Hymenoptera: Apidae: Apinae). American Museum Novitates 3501: 1-60.

Santos, F. A. R. 1997. Scrophulariaceae do Brasil: morfologia polínica e suas implicações taxonômicas. Ph. D. dissertation. Instituto de Biociências, USP, São Paulo, 187 pp.

Sazima, M. \& I. Sazima. 1989. Oil-gathering bees visit flowers of eglandular morphs of the oil-producing Malpighiaceae. Botanica Acta 102: 106-111.

Simpson, B. B. 1989. Krameriaceae. Flora Neotropica. Monograph 49: $1-109$.

Sigrist, M. R. \& M. Sazima. 2004. Pollination biology of twelve species of Neotropical Malpighiaceae: stigma morphology and its implications for the breeding system. Annals of Botany 94: 3341.

Truylio, B.; B. Harter-Marques \& W. Engels. 2002. Biologia floral e polinização de Sysyrinchium micranthum (Iridaceae) na região do Planalto das Araucárias do Rio Grande do Sul, Brasil. Biociências 10: $11-24$.

Vogel, S. 1974. Ölblumen und ölsammelnde Bienen. Tropische und subtropische Pflanzenwelt 7: 1-267.

Vogel, S. \& I. C. Machado. 1991. Pollination of four sympatric species of Angelonia (Scrophulariaceae) by oil-collecting bees in NE. Brazil. Plant Systematics and Evolution 178: 153-178. 